\title{
Variation in NDVI values and relationship with grain yield in two-rowed winter barley
}

\author{
Milan Mirosavljević* · Vojislava Momčilović · Petar Čanak · Vladimir Aćin · \\ Bojan Jocković · Bojana Vujošević
}

Institute of Field and Vegetable Crops, Maksima Gorkog 30, 21000 Novi Sad, Serbia

\begin{abstract}
Summary: The simple methods used for indirect biomass determination are recognized as potentially important tools for crop growth prediction. The normalized difference vegetation index (NDVI) is widely used for assessing crop biomass, yield, photosynthesis, and nitrogen management. Aims of this study were to determine the variation in NDVI values and relationship of the NDVI with the most significant agronomic properties in the elite genotypes of two-rowed winter barley. The experiment included elite two-rowed winter barley genotypes and was carried out in two growing seasons. NDVI were measured at mid-anthesis, while grain yield and grain yield components were determined from combine harvested samples at maturity. Results from this study showed that the influence of genotype was mainly responsible for variation in most studied traits. Grain yield of two-rowed barley cultivars was more related to high grain number per unit area than to grain weight. NDVI values at anthesis in both growing seasons were positively associated with grain yield $\left(\mathrm{R}^{2}=0.444\right.$ and $\left.\mathrm{R}^{2}=0.386\right)$, grain number $\left(\mathrm{R}^{2}=0.387\right.$ and $\left.\mathrm{R}^{2}=0.507\right)$ and plant height $\left(\mathrm{R}^{2}=0.352\right.$ and $\left.\mathrm{R}^{2}=0.364\right)$, while relationship with grain weight was not significant. Significant genotypic variation for NDVI values and the presence of significant positive relationship with grain yield and grain number indicated that NDVI measurement at anthesis could be efficiently used for indirect identification of productive two-rowed winter barley genotypes.

Keywords: biomass, grain number, grain weight, Hordeum vulgare, NDVI, reflectance indices
\end{abstract}

\section{Introduction}

Field and laboratory crop analyses have gained increased importance in the last few decades, in addition to the measurement of main agronomic traits (Sukumaran et al., 2017; Slafer et al., 2015). Field phenotyping, which includes different physiological traits such as gas exchange, canopy temperature, reflectance indices, provides valuable information about crop adaptation to unfavourable environmental conditions, such as high temperature, water or nutrient deficit (Reynolds \& Langridge, 2016).

The comparison of phenotypic changes in representative historical set of cultivars (Beche et al., 2014) enables the identification of agronomic or physiological traits that are directly related to yield. After identification of potential physiological traits that

Corresponding author:

milan.mirosavljevic@ifvcns.ns.ac.rs

Acknowledgment:

This study is part of the project TR31066 "Modern breeding of small grains for present and future needs" financed by the Ministry of Education, Science and Technological Development of the Republic of Serbia. showed a significant relationship with the grain yield and yield components, measurement of these traits could be efficiently utilized in breeding programs (Cossani \& Reynolds, 2012). Primarily, such methods could be used to identify elite parental material that possesses valuable agronomic traits for strategic crossings (Richards et al., 2010). Moreover, additional analysis of genetic resources, which generally have poor agronomic traits, could identify genotypes tolerant to conditions of different abiotic stress, and can be involved in creating new genetic variability (Driever et al., 2014). The application of these methods in early generation selection could increase the frequency of genes associated with crop adaptation before yield testing trials (Reynolds \& Langridge, 2016).

The properties and changes of the photosynthetic area have a significant effect on the potential crop yield (Christopher et al., 2016). Therefore, evaluation of photosynthetic area of crop canopy and related traits such as crop biomass provide essential information for crop production and breeding programs (Casadesús et al., 2007; Pedro et al., 2011). During the previous period, analyses of crop biomass production were mainly destructive (Pržulj \& Momčilović, 2011), time- 
consuming and labour-intensive, and interfered with further analysis of grain yield and other important grain yield determining traits from the plots. Therefore, the simple methods used for indirect determination of crop biomass and canopy traits are recognized as potential important tools for crop growth prediction (CabreraBosquet et al., 2011). Among the numerous physiological methods used for analysis of canopy properties, the normalized difference vegetation index (NDVI) represents one of the most widely used techniques used for assessing crop biomass, yield and other traits (Hazratkulova et al., 2012). NDVI is calculated from measurements of light reflectance in the red $\left(R_{R E D}-660 \mathrm{~nm} \lambda\right)$ and near infrared $\left(R_{\text {NIR }}-660 \mathrm{~nm} \lambda\right)$ regions of the spectrum as NDVI $=$ $\left(R_{N I R}-R_{R E D}\right) /\left(R_{N I R}+R_{R E D}\right)$. A healthy green canopy will adsorb most of the red light and reflect most of the near infrared light. This method is fast and non-destructive, and therefore could be used as additional selection criteria in the assessment of crop biomass during different phenological phases. The information about crop biomass is valuable for plant breeders, since biomass at anthesis and maturity is closely related to yield in different environmental conditions (Mirosavljević et al., 2015a).

Given the rapid and simple application of NDVI analysis under field conditions, aims of this study were to determine the variation in NDVI values, as well as relation of the NDVI with the most significant agronomic properties in the elite genotypes of tworowed winter barley.

\section{Materials and Methods}

The experiment was conducted in 2015/16 and 2016/17 growing seasons at the experimental field of Institute of Field and Vegetable Crops, Novi Sad, Serbia $\left(45^{\circ} 20^{\prime} \mathrm{N}\right.$ and $\left.19^{\circ} 51^{\prime} \mathrm{E}\right)$, on a non-carbonate chernozem soil with soybean as the preceding crop. The experimental material for this study consisted of 23 tworowed winter barley genotypes. The experimental plot size was $1.0 \mathrm{~m}$ wide and $5 \mathrm{~m}$ long, with $0.1 \mathrm{~m}$ spacing between rows. The trials were arranged in randomized complete block design with four replications. The trials were sown on 8 October 2015 and 10 October 2016 with target density of 400 plants per $\mathrm{m}^{2}$. Nitrogen $(\mathrm{N})$, phosphorus $(\mathrm{P})$, and potassium $(\mathrm{K})$ were applied before sowing to avoid $\mathrm{N}, \mathrm{P}$, and $\mathrm{K}$ deficit (average dose was c. $60 \mathrm{~kg} \mathrm{~N} \mathrm{ha}{ }^{-1}, 60 \mathrm{~kg} \mathrm{P} \mathrm{ha}{ }^{-1}$ and $\left.60 \mathrm{~kg} \mathrm{~K} \mathrm{ha}^{-1}\right)$. At the start of stem elongation period $40 \mathrm{~kg} \mathrm{~N} \mathrm{ha}^{-1}$ was topdressed according to $\mathrm{N}$-min analysis. Where necessary, weeds were manually removed periodically. As required, appropriate chemical applications in spring controlled pests (deltametrine) and diseases (tebuconazole and protiokonazol).

\section{Plant and data analysis}

During growing season, anthesis date (Zadoks 65) was recorded for each genotype and NDVI measurement were conducted at mid-anthesis using
Green seeker (Trimble Industries, Inc., USA). Measurements were taken around midday, by passing the sensor over the middle rows of the plots at the height of approximately $0.50 \mathrm{~m}$. Grain yield (GY) was determined for combine-harvested plots in each of the four replications. Moisture content was determined using grain analysis computer (Model GAC2100, Dickey-John, Auburn, IL) and GY was corrected to 140 $\mathrm{g} \mathrm{kg}^{-1}$ moisture. From the harvested sample, grain weight $(G W)$ was determined from measuring three sets of 300 grains per plot. Number of grains per $\mathrm{m}^{2}$ (GN) was calculated as the ratio of the yield and the grain weight. Plant height $(\mathrm{PH})$ was measured from the ground to the base of the spike on ten main stems in each plot at the milk-stage phase.

Analysis of variance (ANOVA) was performed using Infostat (student version), while regression analysis was performed using GraphPad Prism 5 (2007).

\section{Weather conditions}

Weather data were collected from the meteorological station located at the experimental field (Figure 1). Weather conditions, especially the amount and distribution of precipitation and average daily temperature, were similar in both growing seasons. Air temperature, level and distribution of precipitation in autumn enabled fast emergence and establishment of good plant population. Winter period in 2015/16 was characterized by low temperature, but presence of snow cover enabled good winter survival of barley. High precipitation and favourable temperature in April had positive influence on crop growth during stem elongation period. Grain filling took place in May and June and coincided with the relatively high level of precipitation and moderate daily temperature.

\section{Results}

\section{NDVI, yield and agronomic traits}

Results showed that the influence of genotype was mainly responsible for variation in studied traits (NDVI, GN, GW and PH) in two-rowed winter barley (Table 1), while the influence of genotype by year interaction explained the highest percent of grain yield (GY) variation.

NDVI value at anthesis was 0.784 (Table 2). Averaged over growing seasons NDVI values varied from 0.758 (G3) to 0.815 (G19). Across genotypes, in the second growing season barley tended to have higher values of NDVI. Also, barley genotypes responded differently to variation in weather conditions between growing seasons, as confirmed by significant genotype by growing season interactions.

Averaged over growing seasons, grain yield (GY) showed a range of more than $2000 \mathrm{~kg} \mathrm{ha}^{-1}$ (from 9833 to $11358 \mathrm{~kg} \mathrm{ha}^{-1}$ ). The genotype G19, followed by G21 had the highest average GY, while G4 had the lowest one. Although variation in GY between growing 


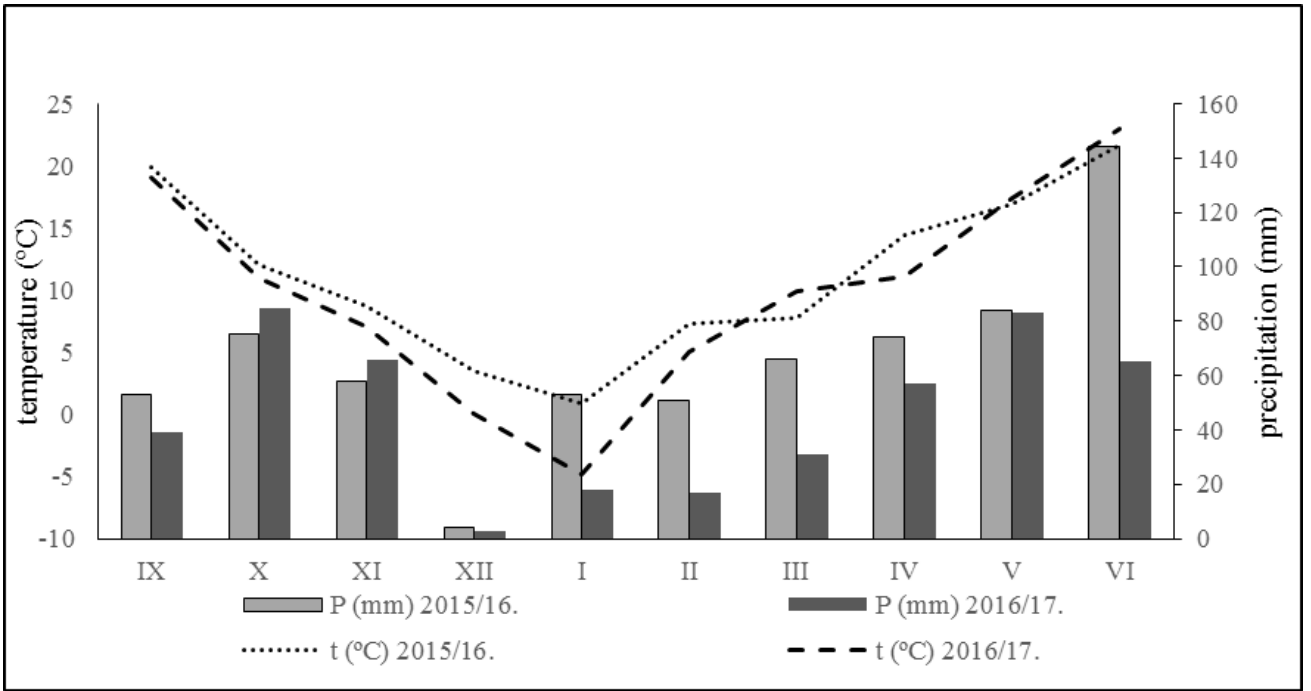

Figure 1. Monthly average daily temperature and precipitation in $2015 / 16$ and $2016 / 17$

seasons was significant, it was less pronounced in relation to the genotypic effect.

There was clear difference in grain number per unit area (GN) among the different growing seasons (20704 and 22140 in 2015/16 and 2016/17, respectively). Across growing seasons, the highest GN was recorded in G11, while G3 had the lowest GN. Studied barley genotypes differed significantly in grain weight (GW), with average GW of $49.5 \mathrm{mg}$. Also, GW varied significantly between growing seasons. Plant height $(\mathrm{PH})$ was $86.3 \mathrm{~cm}$. Across growing seasons, $\mathrm{PH}$ ranged between 79.5 and $93 \mathrm{~cm}$.

\section{Relationship among studied traits}

The linear regression analysis showed presence of significant relationship between NDVI values at anthesis and grain yield (GY) in both growing seasons (Figure 2). GY was more associated with NDVI values in 2015/16. Moreover, there was significant relationship between NDVI and grain number per unit area (GN) in both growing seasons. According to Figure 2, grain weight $(\mathrm{GW})$ was not significantly related with values of NDVI at anthesis in both growing seasons. Highly significant association was found between NDVI values and plant height $(\mathrm{PH})$. Results from Figure 3 showed that variation in grain yield was more related to the establishment of high GN than to GW.

\section{Discussion}

The presence of high genotypic variation in grain yield and grain yield components (Tables 1 and 2) indicated that the genetic diversity within advanced breeding lines could provide useful source of variation for further yield improvements, as previously reported by Gonzalez-Navarro et al. (2016) in wheat and Mirosavljević et al. (2015b) in barley. Grain yield was mainly related to the high grain number per unit area, while relationship with grain weight was less pronounced (Figure 3). Grain number is the main yield determining factor in different cereal crops (Mirosavljevic et al., 2018). On the other hand, most

Table 1. Sum of squares (type III) and percent of variance explained to the total sum of squares of the analysis of variance for the studied parameters across the treatments (year - Y, genotype $-\mathrm{G}$, and genotype by year interaction $-\mathrm{G} \times \mathrm{Y}$; df - degrees of freedom)

\begin{tabular}{|c|c|c|c|c|c|c|}
\hline Source of variation & df & NDVI & GY & GN & GW & $\mathrm{PH}$ \\
\hline Year $(Y)$ & 1 & $229.7 * *$ & $8598101 * *$ & $94778573^{* *}$ & $82.3^{* *}$ & $160.8^{* *}$ \\
\hline Genotype (G) & 22 & $494.7 * *$ & $27742315^{* *}$ & $172079362 * *$ & $441.5^{* *}$ & $1026.4^{* *}$ \\
\hline$G \times Y$ & 22 & $424.1 * *$ & $30323939 * *$ & $135882387^{* *}$ & $362.9^{* *}$ & $917.2 * *$ \\
\hline Error & 138 & 465.4 & 33319094 & 156694266 & 436.4 & 480.7 \\
\hline \multicolumn{7}{|c|}{ Percent of variance explained to the total sum of squares } \\
\hline Year $(Y)$ & & 20 & 12.9 & 23.53 & 9.28 & 7.64 \\
\hline Genotype (G) & & 43.07 & 41.61 & 42.73 & 49.79 & 48.77 \\
\hline $\mathrm{Y} * \mathrm{G}$ & & 36.93 & 45.49 & 33.74 & 40.92 & 43.59 \\
\hline
\end{tabular}

** significant at 0.01 probability level 
Table 2. Average values of normalized difference vegetation index (NDVI)), plant height $(\mathrm{H})$, grain weight $(\mathrm{GW})$, grain number per unit area (GN) and grain yield (GY)

\begin{tabular}{|c|c|c|c|c|c|}
\hline $\begin{array}{l}\text { Treat- } \\
\text { ments }\end{array}$ & NDVI & $\begin{array}{c}\text { GY } \\
\left(\mathrm{kg} \mathrm{ha}^{-1}\right)\end{array}$ & $\begin{array}{l}\text { GN } \\
\left(\mathrm{m}^{-2}\right)\end{array}$ & $\begin{array}{l}\text { GW } \\
(\mathrm{mg})\end{array}$ & $\begin{array}{l}\mathrm{PH} \\
(\mathrm{cm})\end{array}$ \\
\hline G1 & $0.814^{a}$ & $10438^{\mathrm{b}-\mathrm{f}}$ & $21757 \mathrm{~b}$-e & $48.0^{c-e}$ & $88.5^{\mathrm{bc}}$ \\
\hline G2 & $0.790^{\mathrm{a}-\mathrm{d}}$ & $10135^{\mathrm{d}-\mathrm{f}}$ & $21340^{\mathrm{b}-\mathrm{e}}$ & $47.5^{\mathrm{de}}$ & $84.5^{\mathrm{d}}$ \\
\hline G3 & $0.758^{\mathrm{e}}$ & $9958^{\mathrm{ef}}$ & $19272^{\mathrm{f}}$ & $51.7 \mathrm{ab}$ & $79.5^{\mathrm{e}}$ \\
\hline G4 & $0.764 \mathrm{c}-\mathrm{e}$ & $9833^{f}$ & $19893^{\text {ef }}$ & $49.5^{\mathrm{a}-\mathrm{d}}$ & $85.0^{\mathrm{d}}$ \\
\hline G5 & $0.761 \mathrm{de}$ & $10218^{\mathrm{c}-\mathrm{f}}$ & $19978^{\mathrm{d}-\mathrm{f}}$ & $51.3^{\mathrm{ab}}$ & $86.5^{\mathrm{b}-\mathrm{d}}$ \\
\hline G6 & $0.771^{\mathrm{b}-\mathrm{e}}$ & $10393^{\mathrm{b}-\mathrm{f}}$ & $21090^{\mathrm{b}-\mathrm{f}}$ & $49.3^{\mathrm{b}-\mathrm{d}}$ & $86.5^{\mathrm{b}-\mathrm{d}}$ \\
\hline G7 & $0.774 \mathrm{~b}-\mathrm{e}$ & $11080^{a-c}$ & $21759 \mathrm{~b}-\mathrm{e}$ & $51.0^{\mathrm{a}-\mathrm{c}}$ & $85.5^{\mathrm{cd}}$ \\
\hline G8 & $0.780^{\mathrm{b}-\mathrm{e}}$ & $10853^{\mathrm{a}-\mathrm{d}}$ & $22363^{\mathrm{ab}}$ & $48.6^{\mathrm{b}-\mathrm{e}}$ & $89.0^{\mathrm{b}}$ \\
\hline G9 & $0.774 \mathrm{~b}-\mathrm{e}$ & $10438^{\mathrm{b}-\mathrm{f}}$ & $21807^{b-e}$ & $48.0^{c-e}$ & $86.0^{\mathrm{b}-\mathrm{d}}$ \\
\hline G10 & $0.759 \mathrm{e}$ & $10470^{a-f}$ & $20803^{b-f}$ & $50.6^{\mathrm{a}-\mathrm{d}}$ & $85.0^{\mathrm{d}}$ \\
\hline G11 & $0.804^{\mathrm{ab}}$ & $10865^{\mathrm{a}-\mathrm{d}}$ & $23933^{a}$ & $45.5^{\mathrm{e}}$ & $84.5^{\mathrm{d}}$ \\
\hline G12 & $0.790^{\mathrm{a}-\mathrm{e}}$ & $10675^{\mathrm{a}-\mathrm{f}}$ & $21880^{\mathrm{b}-\mathrm{d}}$ & $48.9^{\mathrm{bcd}}$ & $89.0^{\mathrm{b}}$ \\
\hline G13 & $0.793^{\mathrm{a}-\mathrm{d}}$ & $10754^{\mathrm{a}-\mathrm{e}}$ & $21088^{b-f}$ & $51.0^{\mathrm{abc}}$ & $86.0^{\mathrm{b}-\mathrm{d}}$ \\
\hline G14 & $0.791^{\mathrm{a}-\mathrm{e}}$ & $10675^{a-f}$ & $21647^{b-e}$ & $49.4^{\mathrm{a}-\mathrm{d}}$ & $87.5^{\mathrm{b}-\mathrm{d}}$ \\
\hline G15 & 0.789 a-e & $10833^{\mathrm{a}-\mathrm{e}}$ & $21710^{\mathrm{b}-\mathrm{e}}$ & $49.9^{a-d}$ & $87.5^{\mathrm{b}-\mathrm{d}}$ \\
\hline G16 & $0.794^{\mathrm{a}-\mathrm{d}}$ & $10213^{c-f}$ & $21432^{\mathrm{b}-\mathrm{e}}$ & $47.7 \mathrm{de}$ & $86.0^{\mathrm{b}-\mathrm{d}}$ \\
\hline G17 & $0.773^{\mathrm{b}-\mathrm{e}}$ & $10428^{\mathrm{b}-\mathrm{f}}$ & $20817 \mathrm{~b}-\mathrm{f}$ & $50.1^{\mathrm{a}-\mathrm{d}}$ & $86.0^{\mathrm{b}-\mathrm{d}}$ \\
\hline G18 & $0.764 \mathrm{c}-\mathrm{e}$ & $10213 \mathrm{c}-\mathrm{f}$ & $20286 \mathrm{c}-\mathrm{f}$ & $50.5^{\mathrm{a}-\mathrm{d}}$ & $86.0^{\mathrm{b}-\mathrm{d}}$ \\
\hline G19 & $0.815^{\mathrm{a}}$ & $11358^{a}$ & $21717^{\mathrm{b}-\mathrm{e}}$ & $52.5^{a}$ & $87.5^{\mathrm{b}-\mathrm{d}}$ \\
\hline G20 & $0.791^{\mathrm{a}-\mathrm{e}}$ & $11058^{\mathrm{a}-\mathrm{c}}$ & $22408^{\mathrm{ab}}$ & $49.4 \mathrm{a}-\mathrm{d}$ & $85.5^{\mathrm{cd}}$ \\
\hline G21 & $0.795^{a-c}$ & $11138^{a b}$ & $22094^{a-c}$ & $50.4^{\mathrm{a}-\mathrm{d}}$ & $86.0^{\mathrm{b}-\mathrm{d}}$ \\
\hline G22 & $0.796^{\mathrm{a}-\mathrm{c}}$ & $10380^{\mathrm{b}-\mathrm{f}}$ & $21336^{\mathrm{b}-\mathrm{e}}$ & $48.7 \mathrm{bc}-\mathrm{e}$ & $85.0^{\mathrm{d}}$ \\
\hline G23 & $0.796^{\mathrm{a}-\mathrm{c}}$ & $10913^{\mathrm{a}-\mathrm{d}}$ & $22298^{a b}$ & $49.0^{\mathrm{b}-\mathrm{d}}$ & $93.0^{a}$ \\
\hline $2015 / 16$ & $0.773 \mathrm{a}$ & $10363 b$ & $20704 b$ & $50.2 \mathrm{a}$ & $85.4 \mathrm{~b}$ \\
\hline $2016 / 17$ & $0.795 b$ & $10794 a$ & $22140 \mathrm{a}$ & $48.8 \mathrm{~b}$ & $87.3 a$ \\
\hline Average & 0.784 & 10579 & 21422 & 49.5 & 86.3 \\
\hline
\end{tabular}

Different letters indicate significant difference at $\mathrm{P}<0.05$ level

previous studies reported absence of significant association between grain weight and grain yield in wheat (Prado et al., 2017) and barley (Mirosavljević et al., 2016). Grain yield improvement in small grain cereal crops was not followed by significant increase in grain weight with year of cultivar release (Acreche et al., 2008). Generally, plasticity of grain weight is much lower than plasticity of grain number (Sadras \& Slafer, 2012). These results indicated that further grain yield increase in two-rowed barley should be more related with improvements in grain number per unit area.

Although growing season had significant influence on grain yield of small grain cereal crops (Roljević Nikolić et al., 2018), in this study the influence of genotypic effect on barley grain yield and related traits was more pronounced. Generally, both growing seasons were favourable for barley production, since grain yield was similar and remarkably high. According to Figure 1 , weather conditions in spring, primarily favourable rainfall distribution, enabled optimal growth of crops and the achievement of high yields. Suitable weather conditions continued in May (during the grain filling period), which resulted in high values of grain weight.

According to the results from this paper, there was significant genotypic variation in NDVI values at anthesis. These results confirmed the findings of the previous studies (Hazratkulova et al., 2012; Ramya et al., 2015), where NDVI showed high levels of genotypic variability. Also, different environmental conditions, such as nitrogen supply or rainfall distribution, had significant influence at NDVI values (Cabrera-Bosquet et al., 2011). In general, NDVI values varied more among the genotypes than between the growing seasons. Also, presence of significant genotype by year interaction indicated that the studied genotypes responded to environmental variation in different ways.

Generally, NDVI was positively related to grain yield, grain number per unit area and plant height. Positive relationship between NDVI values at anthesis and grain yield was probably the result of high association between NDVI values and crop biomass, as previously reported in different studies (Aparicio et al., 2000; Moges et al., 2005). Moreover, grain yield in tworowed barley is the result of establishing high number of spikes per unit area (Mirosavljevic et al., 2018), and increase in crop biomass is associated with improvement of spike number (Křen et al., 2014). Also, Prado et al. (2017) reported that high biomass was positively related with grain yield in wheat and barley. Therefore, increase of crop biomass at anthesis and maturity represents one of the most important objectives in small grain breeding programs (Zhou et al., 2014). Dry matter accumulated prior to anthesis in vegetative parts could be translocated in grain in order to mitigate negative influence of different undesirable environmental effect (Dordas, 2012). Also, biomass at maturity is directly related to the grain yield through harvest index. Since dry matter production is associated with grain yield, easy estimation of crop biomass at anthesis in different phenological stages represent valuable tool in further breeding programs.

NDVI readings in this experiment were performed during anthesis period, and showed a positive association with yield. However, the association between the NDVI and the biomass (Marti et al., 2007) and grain yield (Morgounov et al., 2014) varied among the phenological phases in which the readings are made. Previous studies reported that the relationship is higher if the measurement is conducted at later stages, such as anthesis or grain filling period (Alvaro et al., 2007; Marti et al., 2007). However, prediction of biomass made at earlier phases (tillering or stem elongation) could be important for adjustment of production measures (Fischer, 1993), primarily the use of appropriate nitrogen doses. 

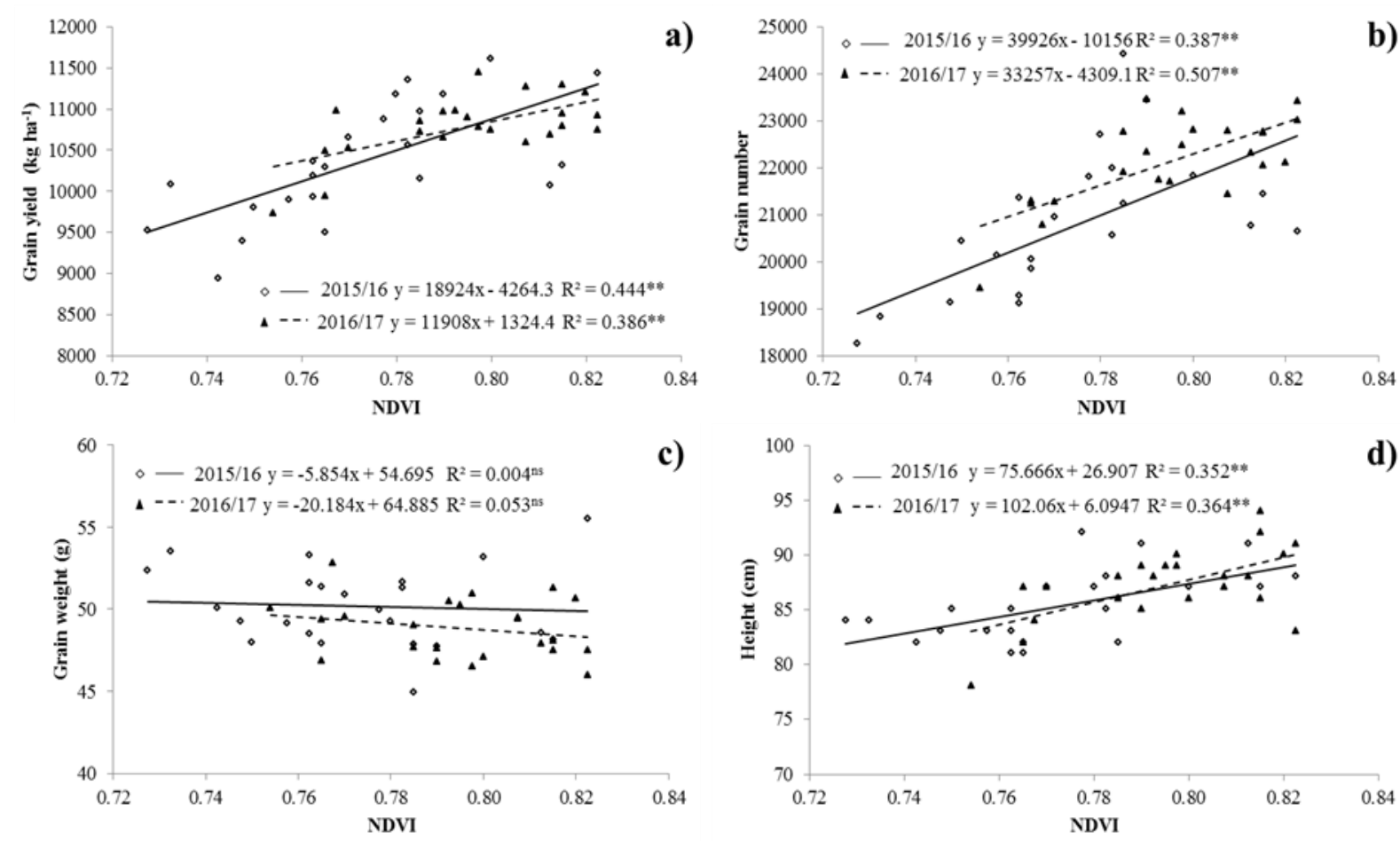

c)

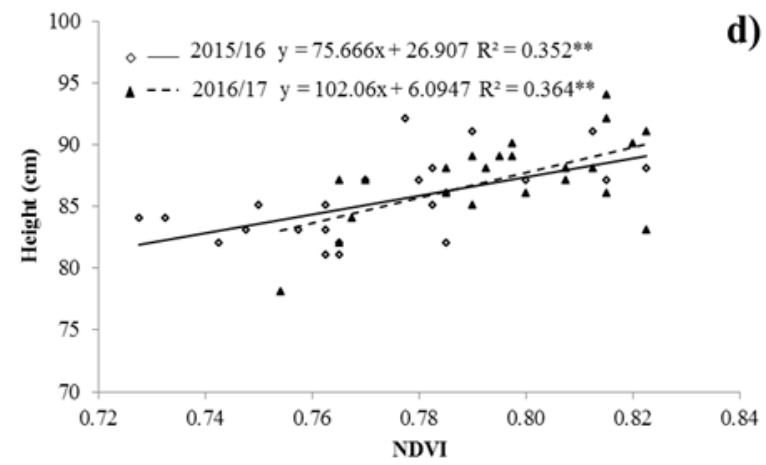

Figure 2. Relationships between NDVI values at anthesis and (a) grain yield, (b) grain number, (c) grain weight and (d) plant height

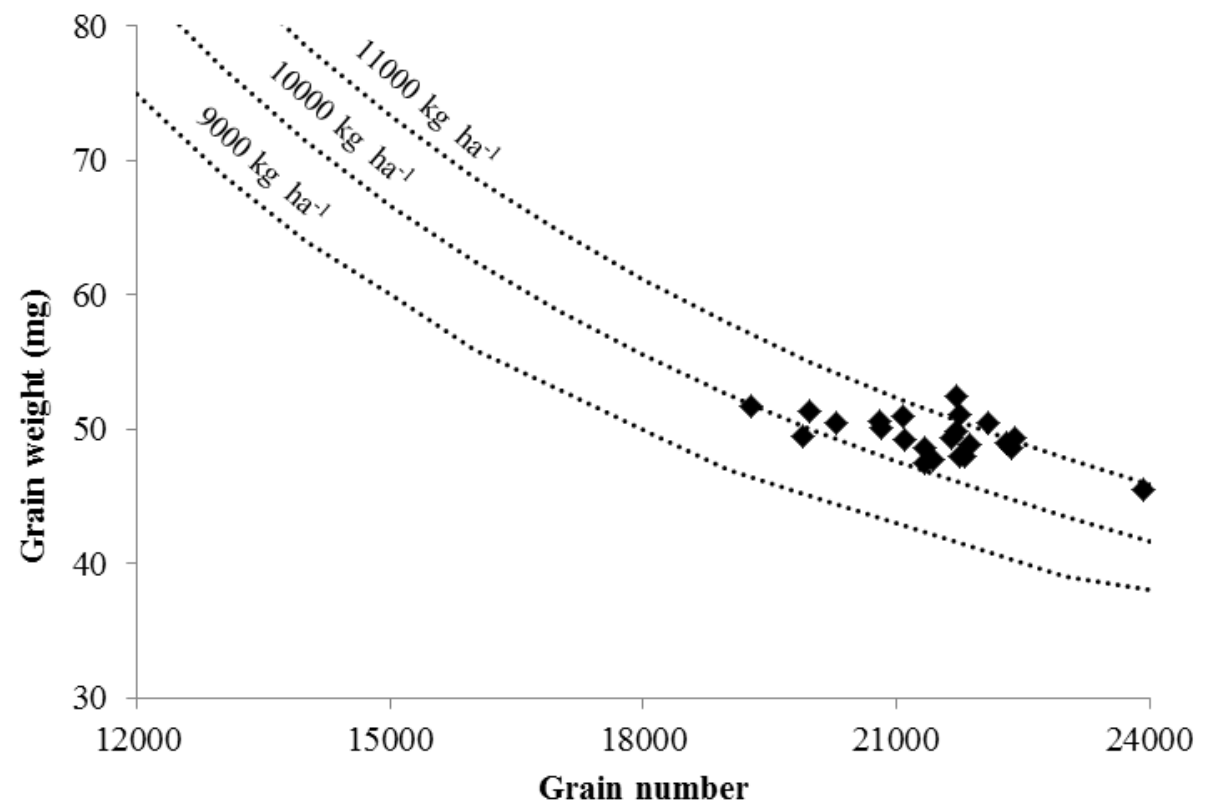

Figure 3. Relationship between grain weight and number of grains per $\mathrm{m}^{2}$; the dotted lines represent lines for iso-grain 


\section{Conclusion}

Growing season, genotype, and their interaction had significant influence on the studied traits in tworowed winter barley. High grain yield was more related to increased grain number per unit area than to grain weight. NDVI values at anthesis in both growing seasons were positively associated with grain yield, grain number and plant height, while relationship with grain weight was not significant. The presence of significant genotypic variation for NDVI values and positive association with grain yield and grain number indicate NDVI measurement at anthesis could be used as additional tool for indirect selection of high yielding two -rowed barley cultivars.

\section{References}

Aparicio, N., Villegas, D., Casadesus, J., Araus, J.L., \& Royo, C. (2000).Spectral vegetation indices as nondestructive tools for determining durum wheat yield. Agronomy Journal, 92(1), 83-91.

Acreche, M.M., Briceno-Felix, G., Martin Sanchez, J.A, \& Slafer, G.A (2008). Physiological bases of genetic gains in Mediterranean bread wheat yield in Spain. European Journal of Agronomy, 28, 162-170.

Beche, E., Benin, G., da Silva, C.L., Munaro, L.B, \& Marchese, J.A. (2014). Genetic gain in yield and changes associated with physiological traits in Brazilian wheat during the 20th century. European Journal of Agronomy, 61, 49-59.

Cabrera-Bosquet, L., Molero, G., Stellacci, A., Bort, J,, Nogues, S. \& Araus, J.L. (2011). NDVI as a potential tool for predicting biomass, plant nitrogen content and growth in wheat genotypes subjected to different water and nitrogen conditions. Cereal Research Communication, 39(1), 147-159.

Casadesús, J., Kaya, Y., Bort, J., Nachit, M.M., Araus, J.L., Amor, S., Ferrazzano, G., Maalouf, F., Maccaferri, M., Martos, V., Ouabbou, H., \& Villegas, D. (2007). Using vegetation indices derived from conventional digital cameras as selection criteria for wheat breeding in water-limited environments. Annals of Applied Biology, 150(2), 227-236.

Christopher, J.T., Christopher, M.J., Borrell, A.K., Fletcher, S., \& Chenu, K. (2016). Stay-green traits to improve wheat adaptation in well-watered and water-limited environments. Journal of Experimental Botany, 67(17), 5159-5172.

Cossani, C.M, \& Reynolds, M.P. (2012). Physiological traits for improving heat tolerance in wheat. Plant physiology, 160(4), 1710-1718.

Driever, S.M., Lawson, T., Andralojc, P.J., Raines, C.A., \& PARRY, M.A.J. (2014). Natural variation in photosynthetic capacity, growth, and yield in 64 field-grown wheat genotypes. Journal of Experimental Botany, 65, 1-15.

Dordas, C. (2012). Variation in dry matter and nitrogen accumulation and remobilization in barley as affected by fertilization, cultivar, and source-sink relations. European Journal of Agronomy, 37(1), 31-42.

Fischer, R.A. (1993). Irrigated spring wheat and timing and amount of nitrogen fertilizer. II. Physiology of grain yield response. Field Crops Research, 33, 57-80.

Gonzalez-Navarro, O.E., Griffiths, S., Molero, G., Reynolds, M.P., \& Slafer, G.A. (2016). Variation in developmental patterns among elite wheat lines and relationships with yield, yield components and spike fertility. Field Crops Research, 196, 294-304.

Hazratkulova, S., Sharma, R.C., Alikulov, S., Islomov, S., Yuldashev, T., Ziyaev, Z., Khalikulov, Z., Ziyadullaev, Z., \& Turok, J. (2012). Analysis of genotypic variation for normalized difference vegetation index and its relationship with grain yield in winter wheat under terminal heat stress. Plant Breeding, 131(6), 716-721.

Křen, J., Klem, K., Svobodová, I., Míša, P., \& Neudert, L. (2014). Yield and grain quality of spring barley as affected by biomass formation at early growth stages. Plant and Soil Environment, 60(5), 221-227.
Marti, J., Bort, J., Slafer, G.A., \& Araus, J.L. (2007). Can wheat yield be assessed by early measurements of normalized difference vegetation index? Annals of Applied Biology 150(2), 253-257.

Mirosavljević, M., Pržulj, N., Momčilović, V., Hristov, N., \& Maksimović, I. (2015a). Dry matter accumulation and remobilization in winter barley as affected by genotype and sowing date. Genetika, 47(2:751-763.

Mirosavljević, M., Pržulj, N., Čanak, P., Momčilović, V., Aćin, V., Jocković, B., Hristov, N., \& Mladenov, N. (2015b). Relationship between grain yield and agronomic traits in winter barley. Ratarstvo i Pourtartarstvo, 52(2), 74-79.

Mirosavljević, M., Momčilović, V., Pržulj, N., Hristov., N., Aćin, V., Čanak, P., \& Denčić, S. (2016). The variation of agronomic traits associated with breeding progress in winter barley cultivars. Žemdirbyste (Agriculture), 103(3), 267-272.

Mirosavljević, M., Momčilović, V., Denčić, S., Mikić, S., Trkulja, D., \& Pržulj, N. (2018). Grain number and grain weight as determinants of triticale, wheat, two-rowed and six-rowed barley yield in the Pannonian environment. Spanish Journal of Agricultural Research, 16(3), e0903.

Moges, S.M., Raun, W.R., Mullen, R.W., Freeman, K.W., Johnson, G.V., \& Solie, J.B. (2005). Evaluation of green, red, and near infrared bands for predicting winter wheat biomass, nitrogen uptake, and final grain yield. Journal of Plant Nutrition, 27(8), 1431-1441.

Morgounov, A., Gummadov, N., Belen, S., Kaya, Y., Keser, M., \& Mursalova J. (2014). Association of digital photo parameters and NDVI with winter wheat grain yield in variable environments. Turkish Journal of Agriculture and Forestry, 38(5), 624-632.

Prado, S.A., Jgallardo, M., Kruk, B.C., Miralles, D.J. (2017). Strategies for yield determination of bread wheat and two-row barley growing under different environments: A comparative study. Field Crops Research, 203, 94-105.

Pržulj, N., \& Momčilović, V. (2011). Characterization of vegetative and grain filling periods of winter wheat by stepwise regression procedure: I. Vegetative period. Genetika, 43(2), 349-359.

Ramya, K.T., Jain, N., Ramya, P., Singh, P.K., Arora, A., Singh, G.P. \& Prabhu, K.V. (2015). Genotypic variation for normalized difference vegetation index and its relationship with grain yield in wheat under terminal heat stress. Indian Journal of Genetics and Plant Breeding, 75(2), 174-182.

Reynolds, M., \& Langridge, P. (2016). Physiological breeding. Current Opinion in Plant Biology, 31: 162-171.

Reynolds, M., Manes, Y., Izanloo, A., \& Langridge, P. (2009) Phenotyping approaches for physiological breeding and gene discovery in wheat. Annals of Applied Biology, 155, 309-320.

Richards, R.A., Rebetzke, G.J., Watt, M., Condon, A.G., Spielmeyer, W., \& Dolferus, R. (2010). Breeding for improved water productivity in temperate cereals: phenotyping, quantitative trait loci, markers and the selection environment. Functional Plant Biology, 37, 85-97.

Roljević-Nikolić, S., Kovačević, D., Cvijanović, G., Dolijanović, Ž. \& Marinković, J. (2018). Grain yield and rhizosphere microflora of alternative types of wheat in organic production. Romanian Biotechnological Letters 23(1), 13301-13309.

Sadras, V.O., \& Slafer, G.A. (2012). Environmental modulation of yield components in cereals: heritabilities reveal a hierarchy of phenotypic plasticities. Field Crops Research, 127, 215-224.

Slafer, G.A., Elia, M., Savin, R., García, G.A., Terrile, I.I., Ferrante, A., Miralles, D.J., \& González F G. (2015). Fruiting efficiency: an alternative trait to further rise wheat yield. Food and Energy Security, 4, 92-109.

Sukumaran, S., Lopes, M., Dreisigacker, S., \& Reynolds, M. (2015). Genetic analysis of multi-environmental spring wheat trials identifies genomic regions for locus-specific trade-offs for grain weight and grain number. Theoretical and Applied Genetics, 131(4), 985-998.

Zhou, B., Sanz-Sáez,Á., Elazab, A., Shen, T., Sánchez-Bragado, R., Bort, J., Serret, M.D., \& Araus, J.L. (2014). Physiological traits contributed to the recent increase in yield potential of winter wheat from Henan Province, China. Journal of Integrative Plant Biology, 56(5), 492-504. 


\section{Varijacija NDVI vrednosti i veza sa prinosom kod ozimog dvoredog ječma}

\section{Milan Mirosavljević · Vojislava Momčilović · Petar Čanak · Vladimir Aćin · Bojan Jocković · Bojana Vujošević}

Sažetak: Jednostavne analize koje se koriste za indirektno odredivanje biomase predstavljaju potencijalno značajne metode za predviđanje rasta useva. Normalizovani diferencijalni vegetacioni indeks (NDVI) se često upotrebljava za ocenu biomase, prinosa i drugih osobina. Cilj ovog istraživanja je bilo utvrđivanje varijacije u NDVI vrednostima i veze sa najznačajnijim agronomskim osobinama kod elitnih genotipova dvoredog ozimog ječma. Ogled sa elitnim genotipovima ozimog ječma je izveden tokom dve sezone. Očitavanje NDVI vrednosti je izvršeno tokom sredine cvetanje, dok su prinos zrna i komponente prinosa određene iz uzorka nakon kombajniranja u punoj zrelosti. Rezultati ovog istraživanja ukazuju da je uticaj genotipa predstavaljao osnovni izvor varijacije kod većine proučavanih osobina. Prinos zrna kod genotipova ozimog dvoredog ječma je bio u većoj vezi sa brojem zrna po jedinici površine u odnosu na masu zrna. NDVI vrednosti u cvetanju u obe sezone su bile u pozitivnoj vezi sa prinosom, brojem zrna i visinom biljaka, dok veza sa masom zrna nije bila značajna. Značajna genotipska varijacija za NDVI vrednosti i značajna pozitivna povezanost sa prinosom zrna i brojem zrna ukazuje da vrednosti NDVI u cvetanju mogu da se efikasno koriste za indirektnu identifikaciju produktivnih genotipova ozimog dvoredog ječma.

Ključne reči: biomasa, broj zrna, Hordeum vulgare, indeks refleksije, masa zrna, NDVI 